\title{
Strategi Digital Content Marketing Toyota Yaris Melalui Webisode "Mengakhiri Cinta dalam Tiga Episode"
}

\author{
Janice Chika, Diah Ayu Candraningrum \\ janice.915160019@stu.untar.ac.id,diahc@fikom.untar.ac.id
}

Fakultas Ilmu Komunikasi Tarumanagara

\begin{abstract}
The dynamic changes of the advertising landscape make advertisers need to keep innovating. Advertisements are crafted by considering its missions, messages and media used. Utilizing the new media, Toyota applied new media advertising characteristics such as interactivity and integrated marketing. Content marketing requires consumers' intention to consume its advertisements. Webisode is a form of creative content marketing using short episodic videos. This research uses qualitative methods and case study. Primary forms of data collection are interview and observation and secondary data is collected through literature review. Toyota Yaris' mission for this advertisement is to gain awareness and build product image. Messages that Toyota Yaris is safe, comfortable and stylish is conveyed by storytelling. Media that is being used is new media with social media platform YouTube. New media characteristics are used as a part of their strategy. Webisode is well produced and starring famous actors to attract consumer's interest.
\end{abstract}

Keywords: advertising, content marketing strategy, new media, webisode

\begin{abstract}
Abstrak
Dunia periklanan yang dinamis membuat para pembuat iklan harus selalu berinovasi. Iklan dibuat dengan mempertimbangkan tujuan, pesan dan media yang digunakan. Menggunakan media baru, Toyota menggunakan sifat-sifat iklan media baru seperti interaktivitas dan pemasaran integrasi. Pemasaran konten mengharuskan konsumen untuk datang ke iklan secara sukarela. Maka, harus memberikan nilai tambah agar membangkitkan inisiatif konsumen. Webisode adalah salah satu bentuk kreatif dari pemasaran konsumen menggunakan video pendek episodik. Penelitian ini menggunakan metode kualitatif dengan studi kasus. Metode pengumpulan data primer wawancara dan observasi, data sekunder dengan studi pustaka. Tujuan iklan Toyota Yaris adalah meningkatkan awareness dan membangun citra, pesan bahwa mobil ini aman, nyaman dan stylish disampaikan melalui cerita. Media yang digunakan adalah media baru, dengan media sosial YouTube. Sifat media baru digunakan sebagai bagian dari strategi ini. Untuk menarik minat konsumen menonton, webisode dibuat dengan sebaik mungkin dengan menggunakan tokoh-tokoh perfilman terkenal.
\end{abstract}

Kata Kunci: iklan, media baru, strategi content marketing, webisode

\section{Pendahuluan}

Strategi pemasaran adalah suatu rencana yang memungkinkan perusahaan untuk memanfaatkan sumber daya dengan sebaik-baiknya untuk mencapai tujuan perusahaan. Strategi membantu perusahaan menjadi lebih unggul dibandingkan kompetitornya. Untuk memasarkan produk secara efektif, semua pemasar haruslah merumuskan $4 \mathrm{P}$ pemasaran. Perusahaan harus memasarkan produk yang tepat dengan price (harga) yang tepat, di place (tempat) yang tepat dan menggunakan strategi promosi yang tepat (Parente dan Strausbaugh-Hutchinson, 2014). 
Iklan adalah salah satu bauran promosi yang sangat sering digunakan. Dalam pembuatan sebuah iklan, para pengiklan dituntut untuk membuat keputusan-keputusan utama dalam pembuatan iklan yang baik. Menurut Kotler dalam Sadeghi, Khani, dan Hosseini (2014) ada lima keputusan utama yang dirumuskan dalam 5M yaitu mission, money, message, media dan measurement. Mission atau tujuan iklan dapat berupa memberi informasi, mempersuasi atau mengingatkan tentang produk. Money adalah besarnya biaya pembuatan iklan. Message, yaitu pesan iklan adalah hasil kreatif para pembuat iklan. Media yang digunakan menentukan jumlah paparan terhadap audiens sasaran. Measurement atau pengukuran keberhasilan iklan dapat dilakukan melalui riset untuk mengetahui berapa besar kesuksesan sebuah iklan mencapai tujuannya.

Iklan berfungsi sebagai penghubung sebuah perusahaan kepada pembeli. Untuk menjalankan fungsinya dengan baik, iklan harus mengikuti kemana khalayak sasarannya sedang berada. Dunia yang dinamis membuat lanskap media cepat berubah. Perubahan lanskap media memaksa pengiklan semakin kreatif. Pengiklan tidak hanya kreatif membuat iklan, tetapi juga kreatif mencari media (Clow \& Baack, 2012).

Media baru membuka kesempatan untuk iklan berkembang. Internet adalah salah satu media yang baru dalam dunia periklanan. Asosiasi Penyelenggara Jasa Internet Indonesia (2018) menyatakan bahwa 64,8\% masyarakat Indonesia sudah menggunakan internet. Banyaknya orang yang menggunakan internet membuat iklan memenuhi internet. Moriarty, Mitchell dan Wells (2015) menyatakan bahwa kemudahan yang disediakan oleh teknologi masa kini menantang pengiklan semakin kreatif. Iklan baru harus interaktif, terintegrasi dengan saluran pemasaran lainnya dan global. Iklan baru memugkinkan konsumen untuk berinteraksi dan memberikan umpan balik kepada perusahaan maupun konsumen lainnya. Pemasaran terintegrasi memudahkan konsumen untuk mencari informasi dari saluran komunikasi lain dari perusahaan. Globalisasi memungkinkan pemasar menyebarkan iklannya kepada masyarakat global.

Banyaknya iklan di internet membuat konsumen merasa terganggu (Sandvig, Baja, dan Ross, 2011). Karena itulah, teknik pemasaran konten banyak digunakan. Content marketing memudahkan perusahaan untuk menyampaikan pesan dan berinteraksi dengan konsumennya (Aprilia, Candraningrum, dan Pandrianto). Pemasaran konten adalah teknik pemasaran dengan membuat dan mendistribusikan konten yang relevan dan bernilai. Tujuannya, untuk menarik, mendapatkan dan membuat engagement pada target yang jelas untuk memancing penonton melakukan sesuatu yang menguntungkan pengiklan (Pulizzi \& Barrett, 2009).

Pemasaran konten memberikan sesuatu yang bernilai bagi konsumen, hingga tercipta loyalitas sebagai hasilnya. Setelah hal-hal tersebut tercapai, pemasaran konten akan menaikkan jumlah penjualan secara tidak langsung dalam jangka panjang. Tujuan-tujuan tersebut dapat dicapai dengan berbagai macam cara dan bentuk pengemasan konten.

Webisode (web-series) adalah salah satu bentuk dari pemasaran konten. Kornblum (2007) dalam Peirce dan Tang (2012) mendefinisikan webisode sebagai video scripted singkat yang diunggah ke internet. Penggunaan format webisode sebagai alat pemasaran konten sedang trending akhir-akhir ini. Penggunaan webisode sebagai media iklan adalah bentuk dari iklan non-tradisional, yaitu penempatan produk dan branded entertainment (hiburan bermerek). Penempatan produk adalah memasukkan merek atau produk ke dalam sebuah acara. Sedangkan, hiburan bermerek adalah integrasi dari hiburan dengan iklan dengan memasuk kanya ke dalam sebuah 
cerita dalam media hiburan. Memasukkan produk ke dalam jalan cerita membuat produk semakin terlihat oleh penontonnya (Belch \& Belch, 2012).

Menurut Shitamrong dan Rompho (2015), webisode mempengaruhi sikap dan minat beli konsumen. Penggunaan webisode baik digunakan untuk memberi informasi yang detail kepada penonton karena durasinya yang panjang. Adanya stimulus audio dan visual membuat informasi yang disampaikan jelas. Penggunaan webisode sebagai bentuk iklan sangat lekat dengan storytelling (penyampaian cerita). Minar (2016) mengkategorikan penyampaian cerita sebagai salah satu macam dari value-added content, komunikasi yang diciptakan untuk mendengar sebuah penyampaian cerita tidaklah dipaksakan. Dalam era post advertising ini, konten semacam inilah yang lebih disukai konsumen dan menimbulkan sikap positif terhadap merek. Konsumen yang tertarik dengan konten akan mencari dan membagikannya secara sukarela.

Salah satu merk yang telah sukses membuat webisode yang viral adalah Toyota Yaris. Konten berupa webisode yang berjudul "Mengakhiri Cinta dalam Tiga Episode" yang tiap episodenya berhasil meraih lebih dari 2.7 juta kali ditonton. Selain itu, komentar yang ditinggalkan oleh penonton bernada positif.

Penggunaan media baru dengan teknik beriklan baru ini menarik untuk diteliti. Berdasarkan latar belakang yang sudah dijabarkan, peneliti akan meneliti bagaimana strategi content marketing Toyota Yaris melalui webisode "Mengakhiri Cinta dalam Tiga Episode"? Maka, peneliti akan membuat penelitian yang berjudul "Strategi Digital Content Marketing Toyota Yaris Melalui Webisode 'Mengakhiri Cinta dalam Tiga Episode"”

\section{Metode Penelitian}

Pendekatan yang penulis gunakan dalam melakukan penelitian ini adalah dengan menggunakan pendekatan kualitatif. Menurut Moleong (2018), metode penelitian kualitatif adalah penelitian yang dilakukan untuk memahami fenomena-fenomena yang dialami suatu subjek. Penelitian kualitatif dilakukan secara holistik dan deskriptif melalui kata-kata dan bahasa.

Dalam penelitian ini, metode penelitian yang digunakan adalah studi kasus. Creswell (2013) dalam Khalifah dan Sudayana (2018) mendefinisikan studi kasus sebagai metode penelitian kualitatif yang mengkaji tentang konteks kehidupan yang nyata. Unit analisis yang diteliti dengan studi kasus dapat berupa satu kasus maupun kasus kolektif. Dalam penelitian ini, peneliti akan meneliti satu kasus yaitu penggunaan webisode sebagai strategi content marketing oleh Toyota Yaris.

Subyek yang diteliti dalam penelitian ini adalah Hernu Rasyid, produser dari Cerita Films. Ada pula objek penelitian yang diteliti adalah strategi pemasaran konten digital Toyota melalui webisode "Memutuskan Cinta dalam Tiga Episode".

Data yang digunakan dalam penelitian ini diperoleh melalui metode pengumpulan data wawancara, observasi dan studi pustaka. Wawancara dilakukan dengan Hernu Rasyid sebagai produser webisode, RTS Masli sebagai narasumber ahli periklanan, Anishka Syafrani sebagai copywriter agensi iklan dan dua penonton yang sesuai dengan target pasar Toyota Yaris.

\section{Hasil Penemuan dan Diskusi}

Saat meluncurkan produk barunya Toyota New Yaris, Toyota membutuhkan komunikasi pemasaran untuk memasarkan produknya melalui promosi. Untuk 
melakukan promosi yang baik, dibutuhkan strategi promosi yang kuat. Hal pertama yang harus ditetapkan adalah segmentasi pasar, tujuan iklan, pesan iklan dan media yang digunakan untuk beriklan. Menggunakan pengertian dan pengetahuan yang dimiliki, pengiklan membuat strategi untuk mencapai tujuan. Dengan tujuan yang mantap dan pengertian tentang target pasar, promosi dapat berjalan dengan baik.

Target pasar dikelompokkan melalui faktor demografi dan psikografis. Produser iklan Hernu Rasyid dan Copywriter Anishka Syafrani mengatakan bahwa target pasar Toyota Yaris secara demografis adalah kelompok umur 17 sampai 35 tahun dengan pendapatan yang cukup untuk membeli mobil. Secara psikografi, Toyota menyasar masyarakat yang dewasa dan siap membeli mobil. Dari pengetahuan tentang pasar ini, perusahaan menetapkan bauran promosi apa yang akan digunakan, dengan tujuan apa, bagaimana cara mengemas pesan dan media apa yang akan digunakan.

Mengenai tujuan webisode ini, Anishka mengatakan bahwa ada dua tujuan yang ingin dicapai, yaitu meningkatkan awareness tentang produk baru Toyota New Yaris dan membentuk brand image. Citra produk yang ingin ditampilkan adalah Toyota Yaris sebagai mobil yang stylish, aman dan nyaman. Hal ini senada dengan pemahaman Hernu bahwa Toyota ingin meluncurkan Toyota Yaris sebagai produk barunya yang memiliki fitur keamanan terbaru.

Dalam webisode ini, pesan pemasaran utama yang ingin disampaikan adalah mobil Toyota adalah mobil yang aman, nyaman dan stylish. Ketiganya disampaikan melalui cerita dan gaya hidup karakter dalam webisode. Menurut pakar periklanan RTS Masli, agar pesan promosi dapat tersampaikan iklan haruslah menarik dan menghibur. Iklan yang tidak menghibur sulit berhasil, karena penonton dapat langsung menolak karena bosan. Inilah bagian para pembuat iklan untuk menuangkan kreativitas mereka membuat dan mengemas pesan sekreatif mungkin. Maka, kemasan pesan haruslah menghibur, menarik dan persuasif.

Iklan dengan tujuan yang mantap dan pesan yang dikemas dengan baik dan menarik belum menjadi iklan jika belum dimediakan. Proses distribusi iklan dapat dilakukan melalui banyak media, baik media konvensional maupun media nonkonvensional. Dalam memilih media, hal yang paling penting adalah memperhatikan target pasar, media apa yang digunakan oleh target audiens. Jika media yang digunakan salah, media yang dibeli akan menjadi mubazir.

Toyota membuat iklan di kedua media tersebut, media tradisional dan media baru. Iklan televisi dibuat untuk berkomunikasi dengan target pasarnya yang masih menonton televisi. Sedangkan iklan media baru dibuat untuk berkomunikasi dengan target pasar mereka yang sudah tidak menonton TV dan beralih menonton YouTube.

Setelah iklan dirumuskan, dibuat dan ditayangkan, iklan akan diukur kesuksesannya. Key performance indicator yang digunakan adalah jumlah kali ditonton, jumlah likes, sentimen komentar dan pertambahan jumlah subscribers. Webisode ini berhasil meraih hasil yang memuaskan. Ditambah lagi webisode ini mendapatkan sambutan yang baik juga di media sosial lainnya. Bahkan, webisode ini mendapatkan rekognisi dari beberapa ajang penghargaan.

Ada beberapa perbedaan sifat yang menonjol antara iklan media konvensional dengan iklan media baru. Sifat media baru menurut Moriarty, Mitchell dan Wells (2015) adalah interaktivitas dan integrasi. Media konvensional biasanya tidak memungkinkan konsumen untuk berkomunikasi kepada perusahaan. Komunikasi dua arah ini dapat diwujudkan dalam media baru. Dalam kanal media YouTube, bentuk umpan baik dapat terjadi dalam bentuk like, dislike, dan komentar. 
Sifat integrasi dalam iklan media baru memungkinkan sebuah iklan dalam satu kanal media internet dapat ditautkan dengan iklan di kanal media lainnya. Sifat ini juga dimanfaatkan oleh Toyota Indonesia. Menurut tim agensi iklan dxtr yang menangani kampanye iklan Toyota Yaris, kampanye ini dirancang lintas kanal media sosial. Selain di YouTube sebagai media utamanya, Toyota juga menggunakan Instagram, Twitter dan Facebook secara bersamaan untuk ikut mempromosikan video utama yang diunggah di YouTube.

Tidak hanya disitu saja, dxtr juga mengajak beberapa key opinion leader di Instagram untuk mempromosikan webisode ini. Beberapa tokoh Instagram yang mempunyai banyak followers dipilih untuk menyokong kampanye ini. Mereka diberikan akses awal untuk menonton webisode ini dan diminta untuk mengunggah reaksi mereka setelah menonton "Mengakhiri Cinta dalam Tiga Episode" ke akun Instagram mereka.

Begitu juga sebaliknya, video YouTube "Mengakhiri Cinta dalam Tiga Episode" bertautan dengan laman web, Facebook, Twitter dan Instagram Toyota Indonesia. Tautan ini dimasukkan dalam kolom deskripsi video. Selain itu, komentar yang diunggah Toyota di webisode juga mengarahkan penontonnya untuk pergi ke Instagram @ToyotaID.

Menggunakan pemasaran konten sebagai metode beriklan membutuhkan pengiklan memberikan nilai tambah pada konten. Menurut RTS Masli, saat membuat sebuah content marketing di internet hal pertama yang harus dilakukan adalah membangun awareness terhadap web yang ingin dituju. Toyota sebagai perusahaan yang besar dan memiliki sosial media yang sudah ada sejak lama memiliki sudah memiliki banyak pengikut. Pengikut yang sudah ada digunakan sebaik mungkin dan penonton baru diperoleh melalui iklan berbayar untuk trailer dan episode pertama webisode.

Setelah mendapat awareness, muncul pertanyaan "mengapa penonton harus mengunjungi kanal YouTube Toyota" dan "mengapa penonton harus menonton webisode ini". Saat penonton berselancar di internet, mereka terpapar oleh banyak pilihan-pilihan lain yang dapat dikunjunginya. Pengiklan harus memberikan alasan mengapa penonton harus mengunjungi webnya. Pernyataan ini sama seperti yang ditulis oleh Hollebeek dan Macky (2018).

Untuk menarik target pasar Toyota datang ke media sosial Toyota Indonesia, mereka ingin membuat sesuatu yang dekat dengan target mereka, yaitu anak muda. Menurut Anisha, anak muda saat ini dekat dengan YouTube. Milenial sedang gemar menonton televisi, video serial. Lebih jauh lagi, Hernu menyatakan bahwa video sudah menjadi bagian sehari-hari dari generasi muda. Bahkan, mengkonsumsi konten seperti menonton video sudah menjadi kebutuhan bagi generasi muda masa kini.

Anishka dan Hernu sependapat soal nilai tambah yang diberikan oleh webisode ini. Menurut mereka, kualitas video yang baik menjadi nilai tambah untuk kampanye pemasaran konten ini. Toyota tidak bermain-main saat membuat webisode ini. Bisa saja mereka sembarang membuat webisode dengan kualitas yang tidak baik dan hanya mengandalkan artis terkenal sebagai pemainnya, tetapi hal ini tidak dilakukan. Menurut Anishka, konten webisode ini harus dibuat dengan baik agar orang mau menontonnya. Selain itu, pemilihan pemain karakter, penyanyi lagu tema, penulis cerita dan production house juga merupakan bagian dari strategi Toyota. Menurut Anishka, pemilihan tokoh-tokoh ini memberikan nilai tambah untuk konten. Ditambah lagi, pengikut tokoh-tokoh tersebut juga secara otomatis akan mengikuti kampanye 
ini. Selain mengambil bagian dalam pembuatan film, mereka juga menjadi bagian dari promosi webisode ini.

Menurut Hernu, webisode "Mengakhiri Cinta dalam Tiga Episode" adalah salah satu bentuk kreatif dari pemasaran konten. Dalam dunia iklan, semua orang berlomba-lomba untuk membuat sesuatu yang kreatif agar konten tersebut dapat viral. Webisode adalah suatu bentuk kreatif komunikasi perusahaan kepada masyarakat, melalui bercerita.

Penggunaan format webisode ini memungkinkan perusahaan mengiklankan sesuatu melalui cerita. Cerita dirasa Hernu mempunyai peran penting dalam mengiklankan sebuah produk. Istilah populer yang ia gunakan adalah "storytelling is king”. Menurutnya, sudah tidak cukup lagi orang beriklan hanya dengan mengatakan bahwa produknya baik dan meminta penontonnya membeli produknya. Pengiklan harus membangun cerita yang dapat dirasa dekat oleh target pasarnya.

Produk memang ditampilkan dan webisode mengandung pesan promosi. Namun, tidak memberikan ajakan langsung untuk membeli produk atau melakukan sesuatu. Teknik ini sering juga disebut dengan soft selling. Keputusan menggunakan teknik soft selling diambil karena tujuan yang ingin dicapai bukanlah berjualan, melainkan untuk menciptakan awareness dan menciptakan perasaan positif terhadap merek.

Dalam webisode ini Toyota menggunakan teknik product placement. Mobil Toyota Yaris banyak tampil dalam webisode ini karena mobil menjadi bagian hidup para tokohnya. Rio dan Ayu sedang melakukan perjalanan panjang menggunakan mobil Toyota Yaris. Penempatan yang dilakukan natural dan realistis. Penempatan informasi fitur juga tidak dipaksakan dan mengalir sesuai dengan adegan yang ada. Pendekatan product placement yang natural dan realistis dipilih oleh Cerita Films dan Yandy Laurens karena dirasa lebih efektif dibandingkan pendekatan yang berlebihan.

RTS Masli mengatakan bahwa penggunaan storytelling dalam sebuah iklan haruslah bijaksana. Cerita yang dibuat haruslah menyokong tujuan iklan menggunakan strategi iklan. Porsi penggunaan cerita juga harus tepat, tidak berlebihan hingga penonton terganggu dan juga tidak terlalu sedikit sehingga penonton tidak menangkap pesan iklan.

Webisode "Mengakhiri Cinta dalam Tiga Episode" menonjolkan jalan cerita agar penonton tertarik dan nyaman menonton. Hasilnya, jumlah penonton banyak dan engagement baik, tetapi penonton tidak mendapatkan pesan ingin disampaikan. Namun, tujuan Toyota membuat pemasaran konten berupa webisode ini adalah meningkatkan awareness. Dalam hal ini, Cerita Films dapat dikatakan berhasil mencapai tujuan utamanya.

\section{Kesimpulan}

Komunikasi pemasaran adalah hal yang penting bagi sebuah perusahaan. Untuk menjalankan pemasaran dengan baik, dibutuhkan strategi yang kuat. Dalam pembuatan iklan, pengiklan harus memperhatikan komponen-komponen seperti segmentasi pasar, tujuan iklan, pesan iklan dan media yang digunakan. Hal ini akan menjadi pedoman bagi keputusan-keputusan pembuatan iklan selanjutnya. Setelah iklan direncanakan, dibuat dan tayang, iklan akan dievaluasi sesuai dengan key performance indicator yang sudah ditentukan. Hal inilah yang menyatakan apakah sebuah kampanye iklan berhasil dan sesuai tujuan. 
Digital content marketing adalah hal baru yang sering digunakan akhir-akhir ini. Pokok utama dari pemasaran konten adalah memberikan nilai tambah agar penonton mau secara sukarela mengkonsumsi konten yang kita berikan. Nilai tambah tersebut digunakan untuk bersaing dengan kompetitor lainnya. Nilai tambah dapat berupa pemenuhan kebutuhan konsumen atau memberi hiburan.

Webisode adalah salah satu format yang digunakan untuk beriklan melalui pemasaran konten digital. Cara webisode menyampaikan pesan adalah melalui cerita. Biasanya, produk akan masuk sebagai bagian kehidupan tokoh dalam cerita. Webisode adalah salah satu bentuk kreatif komunikasi pemasaran yang sedang banyak digunakan oleh perusahaan karena dinilai efektif untuk mencapai tujuan iklan yang diinginkan.

\section{Ucapan Terima Kasih}

Penulis menyampaikan ucapan terima kasih kepada para narasumber, Pak Hernu Rasyid, Pak RTS Masli, Kak Anishka, Yosua dan Clara. Terima kasih yang sebesar-besarnya penulis sampaikan pada orang tua, teman-teman yang telah memberi banyak dukungan pada penulis.

\section{Daftar Pustaka}

APJII. (2018). Penetrasi \& Profil Perilaku Pengguna Internet Indonesia. September 9, 2019.

Aprilia, L., Candraningrum, D. A., \& Pandrianto, N. (2019). Strategi Content Marketing Untuk Membangun Brand Awareness (Studi Kasus Video Aftermovie Djakarta Warehouse Project). Prologia, 3(1), 177-181.

Belch, G. E., \& Belch, M. A. (2012). Advertising and promotion: An integrated marketing communications perspective 6th. New York: NY: McGraw-Hill.

Clow, K.E. and Baack, D. (2012), Integrated advertising, promotion \& marketing communications. New Jersey: Pearson Prentice Hall.

Hollebeek, L. D., \& Macky, K. (2019). Digital content marketing's role in fostering consumer engagement, trust, and value: Framework, fundamental propositions, and implications. Journal of Interactive Marketing, 45, 27-41.

Kholifah, Siti dan Suyadnya, I Wayan. (2018). Metodologi Penelitian Kualitatif: Berbagi Pengalaman dari Lapangan. Depok: Raja Grafindo Persada.

Minár, P. (2016). Goodvertising as a paradigmatic change in contemporary advertising and corporate strategy. Communication Today, 7(2), 4-17.

Moleong, L. J. (2018). Metodologi Penelitian Kualitatif, Remaja Rosdakarya. Inter Komunika, Stikom InterStudi.

Moriarty Sandra, Nancy Mitchell, William Wells. (2015). Advertising, Principles \& Practice (8th Edition). USA: Pearson Education.

Parente, D., \& Strausbaugh-Hutchinson, K. (2014). Advertising campaign strategy: A guide to marketing communication plans. Cengage Learning.

Sadeghi, T., Hasan Khani, M., \& Ebrahim Hosseini, S. (2014). The investigation of Lavidge and Steiner model's capability in measuring the advertising effectiveness of fire insurance (Case study: Insurance company in Mashhad). European Online Journal of Natural and Social Sciences: Proceedings, $2(3$ (s)), pp-1559.

Sandvig, J. C., Bajwa, D., \& Ross, S. C. (2011). Usage and perceptions of internet ad blockers: an exploratory study. Issues in Information Systems, 12(1), 59-69. 
Sinthamrong, P., \& Rompho, N. (2015). Factors affecting attitudes and purchase intentions toward branded content on webisodes. Journal of Management Policy and Practice, 16(4), 64.

Peirce, L. M., \& Tang, T. (2012). Refashioning television: Business opportunities and challenges of webisodes. International Journal of Business and Social Science, 3(13).

Pulizzi, J., \& Barrett, N. (2009). "Get Content Get Customers"-Turn Prospects into Buyers with Content Marketing. Management Case, 98. 